\title{
PENGARUH LAMA PENYIMPANAN DAN PENAMBAHAN ASAM SITRAT PADA NASI DI RICE COOKER TERHADAP KANDUNGAN NUTRISI
}

\author{
HANY HANDAYANI $^{1}$, TINA DEWI RosAhDi ${ }^{*}$, DAN BAIQ EL VIERA ${ }^{1}$ \\ ${ }^{1}$ Jurusan Kimia, Fakultas Sains dan Teknologi, UIN Sunan Gunung Djati Bandung, \\ Jalan A. H. Nasution No. 105 Cibiru Kota Bandung \\ *alamat email korespondensi: tina_dr@uinsgd.ac.id
}

\begin{abstract}
Informasi Artikel
Abstrak/Abstract

Riwayat Naskah :

Diterima pada 20

November 2017

Diterima setelah

direvisi pada 27

Desember 2017

Diterbitkan pada 29

Desember 2017

Umumnya, nasi merupakan jenis makanan yang dikonsumsi oleh sebagian masyarakat Indonesia. Nasi dimasak oleh masyarakat menggunakan alat pemasak nasi otomati atau disebut dengan rice cooker. Nasi dimasak tanpa dan dengan asam sitrat kemudian dihangatkan selama 48 jam dan dianalisis pada jam penghangatan ke-0, 24 dan 48 jam. Penelitian ini bertujuan untuk mengidentifikasi pengaruh lama penyimpanan dan penambahan asam sitrat pada nasi di rice cooker terhadap kadar air, kadar abu, kadar lemak, kadar nitrogen total, karbohidrat total, serat kasar dan menentukan Bahan Ekstrak Tanpa Nitrogen (BETN) pada nasi tanpa dan dengan asam sitrat. Lama penyimpanan nasi $(0,24$, dan 48 jam) di rice cooker mempengaruhi kadar air, kadar lemak total, kadar nitrogen total, karbohidrat total, serat kasar

Kata Kunci: Nasi; rice cooker; nutrisi; karbohidrat; asam sitrat. dan kadar BETN tetapi tidak mempengaruhi kadar abu. Penambahan asam sitrat pada nasi di rice cooker mempengaruhi kadar lemak total dengan penyimpanan selama 0 ke 24 mengalami penurunan, sedangkan pada penyimpanan 24 ke 48 jam mengalami kenaikan kadar lemak total.

Keywords: Rice; rice cooker; nutrition; carbohydrate; citric

Generally, rice is a kind of food that most comsumed by indonesian. rice was cooked using automatic rice cooker equipment, or we know it as rice cooker. The rice which was cooked with and without citric acid and then warmed for about 48 hours and analyzed by the time of warming process of minutes 0,24 and 48 hours. This research aimed to identify the influence of saving length and addition citric acid in the rice cooker on the content water, ash, fat, total carbohydrate, crude fiber and Nitrogen-Free Extract (NFE) formation in the rice cooked with and without citric acid that warmed for 0, 24 and 48 hours using rice cooker. The warming time on the cooked rice (0,24, and 48 hours) affect the content of water, total fat, total nitrogen, total carbohydrate, crude fiber and NFE, without affecting the ash content. The addition of citric acid on the cooked rice during warming time 0 to 24 hours decrease the total fat content, while on the cooked rice during warming time 24 to 48 hours increases the total content.
\end{abstract}

\section{PENDAHULUAN}

Beras adalah salah satu bahan pokok rakyat Indonesia yang mudah disajikan dan mempunyai nilai energi yang cukup tinggi, sehingga berpengaruh terhadap aktivitas tubuh dan kesehatan. Komposisi umum bahan makanan baik yang berasal dar hewan maupun tumbuhan terdiri dari protein, lemak dan zat besi, masing-masing sebesar $63,11 \%, 37,7 \%$ dan $25,30 \%$ dari total kebutuhan tubuh. Nasi merupakan jenis makanan yang dikonsumsi oleh sebagian besar masyarakat indonesia. Nasi dapat dimasak dengan cara tradisional maupun modern. Secara modern, nasi dimasak dengan cara merebusnya dengan air menggunakan alat penanak nasi atau biasa disebut dengan rice cooker [1]. Rice cooker adalah alat rumah tangga listrik yang berfungsi atas dasardasar elemen pemanas. Penyimpanan di rice cooker dibantu menggunakan listrik, maka suhu yang dihasilkan lebih tinggi dibandingkan memasak nasi dengan cara ditanak atau dikukus [2].

Asam sitrat merupakan asam organik lemah yang mudah didapat di pasaran dengan harga terjangkau. Penggunaan dalam skala rumah tangga yaitu sebagai pengawet makanan, pemberi rasa masam, sebagai pembersih pakaian dan lain-lain. Asam sitrat aman digunakan karena mampu dimetabolisme di dalam tubuh dan berfungsi sebagai antioksidan serta dikategorikan aman digunakan pada makanan oleh semua badan pengawasan makanan Nasional dan Internasional dengan kadar yang telah ditentukan [3].

Pada penelitian ini, akan ditentukan kandungan nutrisi pada nasi tanpa dan dengan asam sitrat di rice cooker dengan variasi waktu penyimpanan 0,24 dan 48 jam yang meliputi parameter kadar air, kadar abu, kadar lemak total, kadar nitrogen total, karbohidrat total, kadar serat 
kasar dan Bahan Ekstrak Tanpa Nitrogen (BETN), kemudian akan dibandingkan pengaruh penambahan asam sitrat. Hasil perbandingan ini dilanjutkan dengan perbandingan kesignifikanan secara statistik menggunakan uji t.

\section{EKSPERIMEN}

\section{Material}

Bahan-bahan yang digunakan dalam penelitian ini adalah beras putih dengan merek jembar sukur, asam nitrat monohidrat P.a, asam sulfat $0,255 \mathrm{~N}$, n-heksana teknis, $\mathrm{K}_{2} \mathrm{SO}_{4} 10 \%$, $\mathrm{NaOH} 0,313 \mathrm{~N}$, etanol $95 \%$ teknis dan kertas saring.

\section{Instrumentasi}

Alat penelitian yang digunakan meliputi rice cooker merek Miyako berukuran $1 / 2 \mathrm{Kg}$, batang pengaduk, kaca arloji, gelas kimia, 100, 150, 250 dan $1000 \mathrm{~mL}$, labu ukur 10, 25, 50, 100, 250 dan $500 \mathrm{~mL}$, corong, alat soxhlet, hit hot plate, cawan porselen, pipet seukuran $1,5 \mathrm{~mL}$, termometer, oven dan Furnace.

\section{Prosedur}

Pemasakan nasi dilakukan sebanyak 2 kali. Pertama tanpa ditambahkan dengan asam sitrat dan kedua dengan asam sitrat. Asam sitrat yang digunakan dlarutkan dengan air, kemudian ditambahkan pada saat sebelum dilakukan pemasakan. Setelah itu, dilanjutkan dengan penghangatan di rice cooker selama 0,24 , dan 48 jam. Pengujian dilakukan sampling dengan variasi waktu penyimpanan untuk analisis kadar air, kadar abu, kadar lemak total dengan metode soxhlet, kadar nitrogen total dengan metode Kjeldahl, kadar serat kasar, serta ditentukan BETN dengan analisis proksimat.

\section{Pemasakan dan Preparasi sampel}

Beras putih yang digunakan sebanyak $1 / 2$ Kg. Proses pemasakan sebanyak 2 kali. Beras tanpa asam sitrat dicuci dan ditambahkan dengan air sebanyak $514 \mathrm{~mL}$, kemudian dimasak di ice Cooker. Asam sitrat yang ditambahkan pada beras sebanyak 0,035 gram $(70 \mathrm{mg} / \mathrm{Kg})$. Nasi yang sudah matang disimpan dengan variasi waktu penyimpanan 0,24 dan 48 jam.

\section{Kadar Air}

Cawan kosong dikeringkan dalam oven pada suhu $100-105{ }^{\circ} \mathrm{C}$ selama 15 menit, diambil, didinginkan dalam desikator, kemudian ditimbang sampai didapat berat konstan. Sampel nasi sebanyak 5 gram dimasukkan ke dalam cawan yang telah dikeahui massanya, kemudian dipanaskan dalam oven pada suhu yang sama, diambil, didinginkan dan dipanaskan sampai didapat berat konstan.

\section{Kadar Abu}

Cawan kosong dipanaskan dalam suhu 100$105^{\circ} \mathrm{C}$ selama 15 menit, diambil dan didinginkan dalam desikator kemudian ditimbang. Sampel nasis sebanyak 5 gram dimasukkan ke dalam cawan yang sudah diketahui beratnya, kemudian dipanaskan pada suhu $550{ }^{\circ} \mathrm{C}$ menggunkan Furnace selama 5 jam. Sampel diambil, didinginkan di dalam desikator dan ditimbang.

\section{Kadar Nitrogen Total dengan Metode Mikro Kjeldahl}

Sampel ditimbang $(0,2-0,5 \mathrm{~g})$ dalam labu Kjeldahl $30 \mathrm{~mL}$ dan ditambahkan $2 \mathrm{~g} \mathrm{~K}_{2} \mathrm{SO}_{4}$ dan 2 $\mathrm{mL} \mathrm{H}_{2} \mathrm{SO}_{4}$ pekat. Sampel didekstruksi selama 11,5 jam atau sampai cairan menjadi jernih. Cairan didinginkan, ditambahkan 8-10 $\mathrm{mL} \mathrm{NaOH}-$ $\mathrm{Na}_{2} \mathrm{SO}_{3}$ dan dipasangkan pada alat destilasi. Hasil destilasi ditampung dalam Erlenmeyer yang berisi larutan $\mathrm{H}_{2} \mathrm{BO}_{3}$ dan beberapa tetes indikator metil merah. Ujung selang kondensor diletakkan dalam larutan untuk menampung hasil destilasi sebanyak $15 \mathrm{~mL}$. Destilat yang didapat dititrasi dengan $\mathrm{HCl}$ 0,02 N sampai warna larutan abu-abu. Prosedur yang sama dilakukan untuk blanko (tanpa sampel). Jumlah titrasi sampel (a) dan titrasi (b) dinyatakan dalam $\mathrm{mL}$ dari $\mathrm{HCl} 0,02$.

\section{Kadar Lemak dengan Metode Soxhlet}

Labu lemak dikeringkan dalam oven. Sampel ditimbang dalam kertas saring sebanyak 5 gram, dibungkus, dan ditutup dengan menggunakan kertas saring. Sampel dalam kertas saring diletakkan dalam ekstraksi soxhlet yang dirangkai dengan kondensor. Larutan n-heksana $50 \mathrm{~mL}$ dimasukkan ke dalam labu lemak, direfluks selama \pm 5 jam sisa pelarut dalam lemak dengan memanaskannya dalam oven. Setelah kering, labu lemak ditimbang. Lemak yang terukur adalah hasil pengurangan labu lemak setelag di soxhlet dikurangi dengan labu kosong awal.

\section{Karbohidrat Total}

Karbohidrat by different $=100 \%-\%$ (Kadar Air Kadar Abu - Kadar lemak Total - Kadar Nitrogen total) 


\section{Kadar Serat Kasar}

Sampel ditimbang sebanyak 5 gram, dimasukkan ke dalam labu destilasi $250 \mathrm{~mL}$, ditambahkan dengan $100 \mathrm{~mL} \mathrm{H}_{2} \mathrm{SO}_{4} \quad 0,255 \mathrm{~N}$ mendidih, kemudian direfluks selama 30 menit, sesekali digoyangkan. Suspensi disaring dengan kertas saring, kemudian dicuci dengan Aqua Dm hingga tidak bersifat asam (diuji dengan $\mathrm{pH}$ universal). Residu dipindahkan ke dalam erlenmeyer. Untuk residu yang tertinggal pada kertas saring saring dicuci dengan $\mathrm{NaOH}$ mendidih sampai semua residu mausk ke dalam erlenmeyer. Sampel direfluks selama 30 menit, disaring dan dicuci dengan $10 \mathrm{~mL} \mathrm{~K}_{2} \mathrm{SO}_{4} 10 \%$. Residu yang dihasilkan dicuci dengan $15 \mathrm{~mL}$ alkohol 95\%, kemudian kertas saring dikeringkan pada suhu $110{ }^{\circ} \mathrm{C}$ selama 2 jam lalu ditimbang. Berat residu sama dengan berat serat kasar.

\section{Bahan Ekstrak Tanpa Nitrogen (BETN)}

BETN $=100 \%-\%($ Kadar Air - Kadar Abu - Kadat lemak Total - Kadar serat Kasar - Kadar Nitrogen total)

\section{HASIL DAN PEMBAHASAN}

\section{Pemasakan}

Pemasakan nasi dilakukan menggunakan rice cooker bermerek Miyako berukuran $1 / 2 \mathrm{Kg}$. Beras sebelum dimasak dicuci dengan bersih sampai airnya sedikit jernih. Pemasakan nasi yang digunakan sebanyak $1 / 2 \mathrm{Kg}$ supaya terukur untuk setiap sudut rice cooker yang digunakan dan mudah untuk membandingkan antara permukaan atas, bawah dan samping dari rice cooker. Pada proses pemasakan dicatat waktu untuk mengetahui waktu pengambilan saat penyimpanan berikutnya yaitu 24 dan 48 jam. Asam sitrat yang digunakan adalah asam sitrat monohidrat dengan penggunaan maksimum untuk pengawet yaitu $70 \mathrm{mg} / \mathrm{Kg}$ untuk tepung dan pati, maka untuk banyaknya asam sitrat merujuk pada peraturan. Untuk sampel yag digunakan karena tidak tersedia nasi maka disetarakan dengan tepung dan pati yang kandungannya sebagian besar merupakan karbohidrat.

Pada penambahan asam sitrat, asam sitrat dilarutkan terlebih dahulu dengan air agar asam sitrat tersebut merata dan tidak terpusat pada satu titik tertentu dan ketika proses pemasakan berlangsung asam sitrat ikut terserap oleh nasi. Proses pemasakan terjadi ketika air benar-benar mendidih dan asam sitrat merupakan asam yang memiliki titik didih $175^{\circ} \mathrm{C}$, sehingga ketika proses pemasakan dan air mendidih asam sitrat tidak ikut menguap. Pada saat pemasakan menjadi nasi terjadi perubahan fisik yang disebut dengan gelatinisasi. Proses ini terjadi perubahan suspensi pati keruh menjadi bening akibat perubahan butir pati secara cepat menggunakan medium air panas sebagai akibat proses imbibisi oleh granula pati yang bersifat reversibel. Perubahan pati secara cepat di dalam air panas menjadi tajin yang bersifat irreversibel dan menjauhnya susunan rantai karbohidrat yang tadinya melekat, sehingga menimbulkan aktivitas penyerapan air dan terjadi pengembangan butir pati. Pengembangan volume nasi adalah proses mengembangnya beras menjadi nasi selama pemasakan. Pada proses pengembangan ini menyebabkan permukaan butir beras retak yang dipengaruhi oleh kadar amilosa. Semakin tinggi kadar amilosanya maka semakin tinggi pula kandungan airnya, sehingga pengembangan pada nasi akan tinggi pula [4].

Nasi dengan penambahan asam sitrat, didiamkan 5-10 menit saat setelah matang. Nasi dalam keadaan basah dan terdapat uap. Saat dilakukan sampling nasi diambil sedikit bagian atas, samping kanan, samping kiri, tengah sampai bagian bawah. Pengambilan dengan cara tersebut diharapkan dapat mewakili setiap bagian nasi. Setelah nasi diambil, kemudian dipindahkan untuk didinginkan terlebih dahulu kemudian dimasukkan ke dalam toples untuk dilakukan analisis.

\section{Kandungan Nutrisi Nasi di Rice Cooker}

\section{Kadar Air}

Kandungan air pada nasi dari jam ke- 0 dan jam ke-24 mengalami penurunan, hal ini terjadi sebagai akibat lamanya penyimpanan dalam rice cooker, sehingga pada pemanasan tersebut ada kendungan air yang menguap selama penghangatan terjadi, tetapi nasi yang disimpan selama 48 jam mengalami peningkatan kandungan air. Selama penyimpanan, kadar air akan bertambah apabila kelembaban udara sekitar meningkat, selain itu kelembaban udara dan suhu ruang lingkungan mempengaruhi tinggi rendahnya kandungan air. Pada lingkungan rice cooker yang tertutup dan berlangsungnya penghangatan mempengaruhi kadar air. Uap itu kembali ke bagian permukaan dalam rice cooker dan diserap oleh nasi, sehingga mempengaruhi kadar air. Pada Tabel 1. menunjukkan hasil analisis kadar air dan persentase penurunan dan kenaikan setiap penyimpanan. Kadar air pada penyimpanan $0 \mathrm{ke}$ 24 jam mengalami penurunan dengan persentase penurunan $6,09 \%$ sedangkan pada penyimpanan 
24 jam ke 48 jam kadar air mengalami kenaikan kembali dengan persentase kenaikan $4,82 \%$.

Tabel 1. Kadar air dan persentase penurunan atau kenaikan setiap penyimpanan

\begin{tabular}{ccc}
\hline $\begin{array}{c}\text { Waktu } \\
\begin{array}{c}\text { Penyimpanan } \\
\text { (jam) }\end{array}\end{array}$ & $\begin{array}{c}\% \\
\text { kadar } \\
\text { air }\end{array}$ & \% kenaikan/penurunan \\
\hline 0 & 42,87 & $(0 \rightarrow 24) 6,09 \%$ (turun) \\
24 & 40,26 & $(24 \rightarrow 48) 4,82 \%$ (naik) \\
48 & 42,20 & \\
\hline
\end{tabular}

\section{Kadar Abu}

Kadar abu pada nasi tanpa asam sitrat tidak ada perubahan baik pada penyimpanan 0,24 dan 48 jam. Setiap pengukuran kadar abu menggunakan suhu $550^{\circ} \mathrm{C}$ selama 5 jam. Pada suhu tersebut kandungan air, kandungan organik lain menguap yang tersisa adalah mineralnya, maka kadar abu ini diperkirakan kandungan mineral total yang terkandung dalam nasi.

\section{Kadar Nitrogen Total}

Pada kadar nitrogen total, nasi tanpa asam sitrat mengalami penurunan setara dengan kenaikan lamanya penyimpanan yaitu semakin lama penyimpanan maka semakin menurun kandungan nitrogen total tersebut. Sesuai dengan sifat-sifat protein yang rentan terhadap suhu, sehingga ketika dipanaskan dengan waktu yang lama akan mengalami penurunan. Tabel 2. menunjukkan kadar nitrogen total dan persentase penurunan atau kenaikan setiap penyimpanan nasi.

Tabel 2. Kadar nitrogen total dan persentase penurunan atau kenaikan setiap penyimpanan nasi

\begin{tabular}{ccc}
\hline $\begin{array}{c}\text { Waktu } \\
\begin{array}{c}\text { Penyimpanan } \\
\text { jam) }\end{array}\end{array}$ & $\begin{array}{c}\text { \% kadar } \\
\text { nitrogen } \\
\text { total }\end{array}$ & \% kenaikan/penurunan \\
\hline 0 & 7,30 & $(0 \rightarrow 24) 13,15 \%$ (turun) \\
24 & 6,34 & $(24 \rightarrow 48) 8,52 \%$ (turun) \\
48 & 5,80 & \\
\hline
\end{tabular}

\section{Kadar Lemak}

Pada kadar lemak selama 24 jam penyimpana mengalami penurunan dan naik kembali pada penyimpanan 48 jam baik itu pada nasi dengan tanpa dengan asam sitrat. Faktor yang mempengaruhi salah satunya uap yang terkandung pada rice cooker. Tabel 3. menunjukkan persentase masing-masing penyimpanan pada nasi di rice cooker.
Tabel 3. Kadar lemak dan persentase penurunan atau kenaikan setiap penyimpanan

\begin{tabular}{ccc}
\hline $\begin{array}{c}\text { Waktu } \\
\begin{array}{c}\text { Penyimpanan } \\
\text { (jam) }\end{array}\end{array}$ & $\begin{array}{c}\text { \% kadar } \\
\text { lemak }\end{array}$ & \% kenaikan/penurunan \\
\hline 0 & 0,18 & $(0 \rightarrow 24) 72,22 \%$ (turun) \\
24 & 0,05 & $(24 \rightarrow 48) 70,60 \%$ (naik) \\
48 & 0,17 & \\
\hline
\end{tabular}

\section{Karbohidrat Total}

Karbohidrat total nasi tanpa asam sitrat pada nasi di rice cooker dapat berupa polisakarida, hemiselulosa, lignin dan lain-lain. Karbohidrat total dipengaruhi oleh kadar air, kadar abu, kadar nitrogen total dan kadar lemak total. Semakin tinggi nilai kadar air, kadar abu, kadar nitrogen total dan kadar lemak total maka semakin kecil karbohidrat total. Pada nasi tanpa asam sitrat pada penyimpanan 0 ke 24 jam karbohidrat mengalami kenaikan, akibat dari turunnya kadar air pada penyimpanan ke-24 jam, sedangkan pada penyimpanan ke-48 jam mengalami penurunan. Tabel 4. berikut menunjukkan kadar karbohidrat total dengan persentase penurunan atau kenaikan.

Tabel 4. Karbohidrat total dan persentase penurunan atau kenaikan setiap penyimpanan

\begin{tabular}{ccc}
\hline $\begin{array}{c}\text { Waktu } \\
\begin{array}{c}\text { Penyimpanan } \\
\text { (jam) }\end{array}\end{array}$ & $\begin{array}{c}\text { \% kadar } \\
\text { karbohidrat } \\
\text { total }\end{array}$ & \% kenaikan/penurunan \\
\hline 0 & 49,53 & $(0 \rightarrow 24) 4,40 \%$ (naik) \\
24 & 53,24 & $(24 \rightarrow 48) 2,87 \%$ (turun) \\
48 & 51,71 & \\
\hline
\end{tabular}

\section{Kadar serat kasar}

Hasil pengukuran serat kasar pada berbagai penyimpanan diperlihatkan pada Tabel 5. Pada nasi tanpa asam sitrat terjadi penurunan pada setiap lama waktu penyimpanan diduga karena terjadinya penguraian serat kasar oleh aktifitas mikroorganisme pada nasi. Aktifitas organisme terjadi karena adanya nutrisi yang terkandung dalam serat kasar yaitu polisakarida. Hal ini mengakibatkan organisme memanfaatkan sumber karbon menjadi sumber makanan selama penyimpanan. Penurunan suatu serat kasar dapat dipengaruhi oleh peningkatan kadar air yang mampu mempengaruhi pertumbuhan dan aktifitas mikroorganisme selama penyimpanan. 
Tabel 5. Kadar serat kasar dan persentase penurunan atau kenaikan setiap penyimpanan

\begin{tabular}{ccc}
\hline $\begin{array}{c}\text { Waktu } \\
\text { Penyimpanan } \\
\text { (jam) }\end{array}$ & $\begin{array}{c}\text { \% kadar } \\
\text { serat kasar }\end{array}$ & \% kenaikan/penurunan \\
\hline 0 & 14,00 & $(0 \rightarrow 24) 19,77 \%$ (naik) \\
24 & 17,45 & $(24 \rightarrow 48) 37,99 \%$ (turun) \\
48 & 10,82 & \\
\hline
\end{tabular}

\section{Bahan Ekstrak Tanpa Nitrogen (BETN)}

Pada nasi tanpa asam sitrat, menunjukkan hasil kenaikan pada setiap penyimpanan. BETN dipengaruhi oleh 5 faktor yaitu kadar air, kadar abu, kadar protein Kjeldahl, kadar lemak total dan serat kasar. Kadar air yang terdapat dalam sampel, kadar abu mewakili total mineral, kadar lemak total, kadar protein Kjeldahl mewakili kadar nitrogen total dan serat kasar mewakili serat total yang terdapat dalam sampel. Caranya dengan $100 \%$ dikurangi dengan persentase kadar air, kadar abu, kadar protein Kjeldahl, kadar lemak total, serat kasar diukur per 5 gram pada nasi di rice cooker tanpa asam sitrat. Tabel 6. menunjukkan kadar BETN dan persentase penurunan atau kenaikan setiap penyimpanan.

Tabel 6. Kadar BETN dan persentase penurunan atau kenaikan setiap penyimpanan

\begin{tabular}{ccc}
\hline $\begin{array}{c}\text { Waktu } \\
\begin{array}{c}\text { Penyimpanan } \\
\text { (jam) }\end{array}\end{array}$ & $\%$ BETN & $\%$ kenaikan/penurunan \\
\hline 0 & 35,53 & $(0 \rightarrow 24) 0,73 \%$ (naik) \\
24 & 35,79 & $(24 \rightarrow 48) 12,25 \%$ (turun) \\
48 & 40,89 & \\
\hline
\end{tabular}

\section{Kandungan Nutrisi Nasi Di Rice Cooker dengan Asam Sitrat}

\section{Kadar Air}

Kandungan air pada nasi dengan asam sitrat lebih sedikit dibandingkan diperkirakan karena adanya zat lain yang ikut larut yaitu asam sitrat. Asam sitrat memiliki titik didih lebih tinggi dibandingkan dengan air maka pada saat pemasakan tidak menguap, sehingga ikut terserap oleh nasi. Kadar air pada nasi dengan asam sitrat pada penyimpanan di rice cooker pada 0 ke 24 jam mengalami kenaikan. Hal ini terjadi karena adanya peningkatan kadar air oleh adanya asam sitrat. Asam sitrat yang digunakan berbentuk asam sitrat monohidrat dan akan menjadi anhidrat apabila terjadi pemanasan dengan kisaran suhu yang digunakan $70-75^{\circ} \mathrm{C}$ [5], sehingga pada penyimpanan ke-24 jam di rice cooker kandungan air mengalami peningkatan.
Pada penyimpanan di rice cooker selama 48 jam kadar air mengalami penurunan kembali. Hal ini diperkirakan karena pemanasan secara terus menerus, sehingga kadar air menurun pada waktu 1 kali 24 jam, selain faktor lingkungan rice cooker dan kelembaban sekitar ruang yang mempengaruhi aktifitas air pada nasi. Kadar air pada nasi dengan ditambah asam sitrat pada penyimpanan 0 ke 24 jam mengalami kenaikan $4,13 \%$, sedangkan pada penyimpanan 24 ke 48 jam kadar air mengalami penurunan 1,19\%. Pada Tabel 7. berikut menunjukkan kadar air dan persentase penurunan atau kenaikan kadar air setiap penyimpanan.

Tabel 7. Kadar air dan persentase penurunan atau kenaikan kadar air setiap penyimpanan

\begin{tabular}{ccc}
\hline $\begin{array}{c}\text { Waktu } \\
\begin{array}{c}\text { Penyimpanan } \\
\text { (jam) }\end{array}\end{array}$ & $\begin{array}{c}\text { \% kadar } \\
\text { air }\end{array}$ & \% kenaikan/penurunan \\
\hline 0 & 39,67 & $(0 \rightarrow 24) 4,13 \%$ (naik) \\
24 & 41,31 & $(24 \rightarrow 48) 1,19 \%$ (turun) \\
48 & 40,82 & \\
\hline
\end{tabular}

Berdasarkan teori perubahan fasa dalam termodinamika, apabila makanan ditempatkan pada udara terbuka akan berubah sampai mencapai kondisi seimbang dengan kelembaban nisbi udara yang bersangkutan. Jika kadar air bahan cukup tinggi, maka sebagian akan berubah menjadi gas kemudian masuk ke dalam udara sebagai uap air. Jika kadar air suatu bahan lebih rendah dan udaranya lembab, maka uap air dalam udara akan terserap oleh bahan, sehingga kadar air meningkat [6].

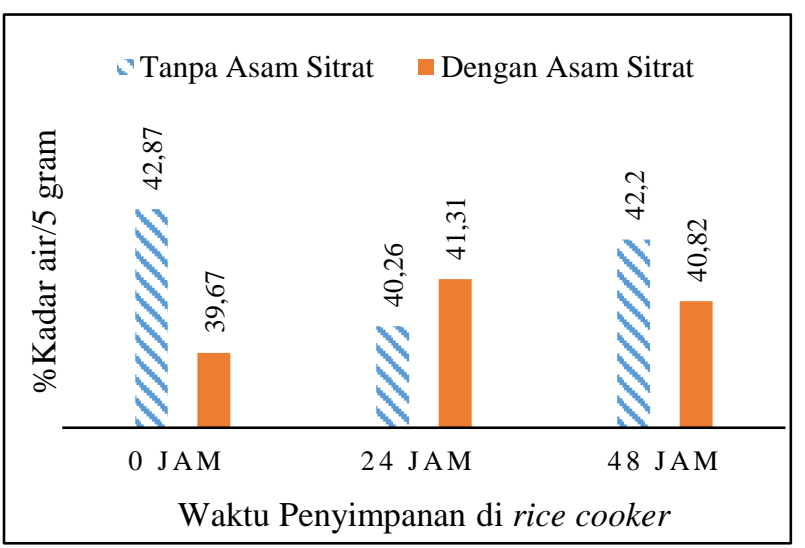

Gambar 1. Hasil analisis kandungan air

Hasil kadar air pada nasi tanpa dan dengan asam sitrat pada penyimpanan 0,24 dan 48 jam berdasarkan uji t menunjukkan perbedaan hasil yang tidak cukup signifikan antara keduanya. Nilai dari t masih masuk ke titik wilayah kritis. Penambahan asam sitrat pada nasi di rice cooker tidak memberikan pengaruh terhadap kandungan 
air. Persentase kenaikan atau penurunan nasi tanpa dan dengan asam sitrat dapat dilihat pada Tabel 8. berikut.

Tabel 8. Persentase penurunan atau kenaikan kadar air setiap penyimpanan pada nasi tanpa dan dengan asam sitrat

\begin{tabular}{cccc}
\hline $\begin{array}{c}\text { Waktu } \\
\begin{array}{c}\text { Penyimpanan } \\
\text { (jam) }\end{array}\end{array}$ & $\begin{array}{c}\text { \% kadar } \\
\text { air tanpa } \\
\text { asam } \\
\text { sitrat }\end{array}$ & $\begin{array}{c}\text { \% kadar } \\
\text { air }(+) \\
\text { asam } \\
\text { sitrat }\end{array}$ & $\begin{array}{c}\text { \%kenaikan } \\
\text { atau } \\
\text { penurunan }\end{array}$ \\
\hline 0 & 42,87 & 39,67 & 7,46 (turun) \\
24 & 40,26 & 41,31 & 2,61 (naik) \\
48 & 42,20 & 40,82 & 3,27 (turun) \\
\hline
\end{tabular}

Kadar Abu

Pada nasi dengan asam sitrat dengan variasi penyimpanan di rice cooker terhadap kadar abu tidak mengalami perubahan. Asam sitrat memiliki titik lebur sekitar $153^{\circ} \mathrm{C}$ maka saat dipanaskan pada suhu $550^{\circ} \mathrm{C}$ akan menguap seluruhnya. Kadar mineral pada nasi dengan asam sitrat tidak terjadi kenaikan atau penurunan, sehingga kadar mineral pada nasi dengan asam sitrat tidak mempengaruhi jumlah mineral yang terdapat pada nasi berbagai penyimpanan di rice cooker.

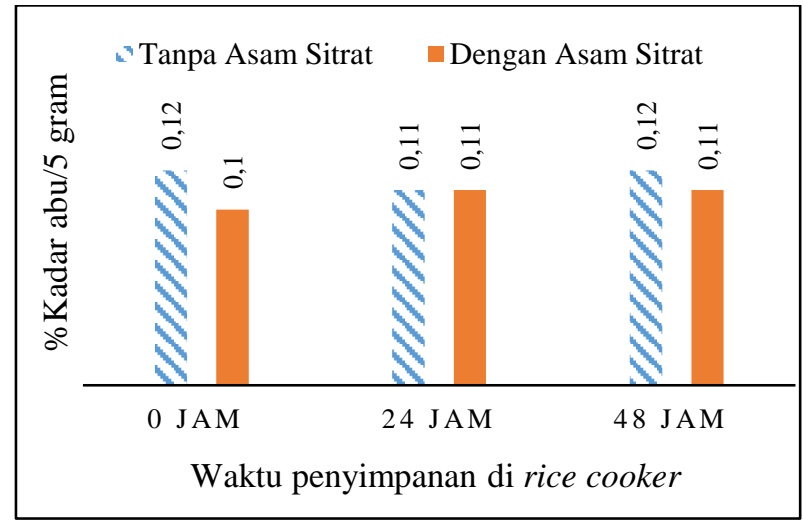

Gambar 2. Hasil analisis kadar abu

Penambahan asam sitrat pada nasi di rice cooker menunjukkan tidak mempengaruhi kandungan mineral. Persentase kadar mineral pada setiap penyimpanan hampir sama, sehingga tidak ada kenaikan atau penurunan pada masing-masing kandungan mineral. Pada Gambar 2. diperlihatkan perbandingan antara nasi tanpa dan dengan asam sitrat menunjukkan tidak ada perubahan yang signifikan yang dibuktikan dengan uji t.

\section{Kadar Nitrogen Total dengan Metode Kjeldahl}

Pada nasi ditambah dengan asam sitrat sedikit berbeda pada persentase nitrogen, diperkirakan karena adanya penambahan asam sitrat yang menurunkan kadar persentase nitrogen total akan tetapi tidak signifikan. Hal ini terjadi, karena protein terdiri dari asam amino. Reaksi ini terjadi adanya perlakuan pada protein seperti pemasakan, penggorengan dan pembakaran. Reaksi dapat terjadi apabila suhu yang digunakan $100-220^{\circ} \mathrm{C}$. Persentase penurunan masing-masing penyimpanan nasi dengan asam sitrat diperlihatkan pada Tabel 9.

Tabel 9. Kadar nitrogen total dan persentase penurunan atau kenaikan setiap penyimpanan

\begin{tabular}{ccc}
\hline $\begin{array}{c}\text { Waktu } \\
\begin{array}{c}\text { Penyimpanan } \\
\text { (jam) }\end{array}\end{array}$ & $\begin{array}{c}\text { \% kadar } \\
\text { nitrogen } \\
\text { total }\end{array}$ & $\begin{array}{c}\text { \% kenaikan/ } \\
\text { penurunan }\end{array}$ \\
\hline 0 & 6,62 & $(0 \rightarrow 24) 13,44 \%$ (turun) \\
24 & 5,73 & $(24 \rightarrow 48) 15,01 \%$ (turun) \\
48 & 4,87 & \\
\hline
\end{tabular}

Berdasarkan uji t hasil kadar nitrogen total pada nasi tanpa dan dengan asam sitrat pada penyimpanan 0,24 , dan 48 jam menunjukkan perbedaan hasil yang tidak siginifikan antara keduanya. Nilai dari uji t masih masuk ke titik wilayah kritis, artinya secara rata-rata memiliki hasil yang sama. Berikut Gambar 3. perbandingan antara \%kadar nitrogen total nasi tanpa dan dengan asam sitrat.

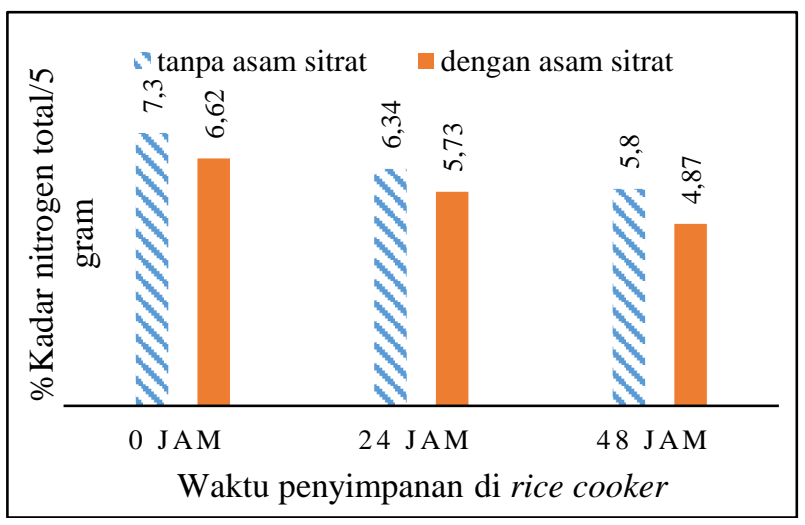

Gambar 3. Hasil analisis persentase nitrogen total

Pada hasil kadar nitrogen total dihitung perbandingan persentase penurunan pada masingmasing penyimpanan, bertujuan untuk melihat perbandingan persentase keduanya. Tinggi rendahnya nilai protein yang terukur dapat dipengaruhi oleh besarnya kandungan air yang hilang (dehidrasi) dari bahan. Nilai protein akan semakin besar jika jumlah air yang hilang semakin besar. Kandungan protein yang terukur tergantung pada jumlah bahan-bahan yang ditambahkan dan sebagian besar dipengaruhi oleh kandungan air [7]. Pada Tabel 10. persentase penurunan atau kenaikan kadar nitrogen total setiap penyimpanan menunjukkan tidak adanya perbandingan yang cukup signifikan antara nasi tanpa dan dengan 
asam sitrat pada nasi di rice cooker kemungkinan tidak mempengaruhi kandungan nitrogen total.

Tabel 10. Persentase penurunan atau kenaikan kadar nitrogen total setiap penyimpanan pada nasi tanpa dan dengan asam sitrat

\begin{tabular}{cccc}
\hline $\begin{array}{c}\text { Waktu } \\
\text { Penyimpa } \\
\text { nan (jam) }\end{array}$ & $\begin{array}{c}\text { \% kadar } \\
\text { nitrogen } \\
\text { total tanpa } \\
\text { asam sitrat }\end{array}$ & $\begin{array}{c}\text { \% kadar } \\
\text { nitrogen } \\
\text { total }(+) \\
\text { asam sitrat }\end{array}$ & $\begin{array}{c}\text { \%kenaikan } \\
\text { atau } \\
\text { penurunan }\end{array}$ \\
\hline 0 & 7,30 & 6,62 & 9,32 (turun) \\
24 & 6,34 & 5,73 & 9,62 (turun) \\
48 & 5,80 & 4,87 & 16,03 (turun) \\
\hline
\end{tabular}

\section{Kadar lemak dengan Metode Soxhlet}

Nasi di rice cooker dengan ditambah dengan asam sitrat menunjukkan perbandingan yang berbeda. Pada persentase kenaikan dan penurunan memberikan perbandingan yang cukup signifikan pada setiap penyimpanan. Tabel 11. menunjukkan persentase penurunan kenaikan kadar lemak setiap penyimpanan.

Tabel 11. Kadar lemak dan persentase penurunan atau kenaikan setiap penyimpanan

\begin{tabular}{ccc}
\hline $\begin{array}{c}\text { Waktu } \\
\begin{array}{c}\text { Penyimpanan } \\
\text { (jam) }\end{array}\end{array}$ & $\begin{array}{c}\text { \% kadar } \\
\text { lemak }\end{array}$ & \% kenaikan/penurunan \\
\hline 0 & 0,09 & $(0 \rightarrow 24) 22,22 \%$ (turun) \\
24 & 0,07 & $(24 \rightarrow 48) 50,00 \%$ (naik) \\
48 & 0,14 & \\
\hline
\end{tabular}

Pada nasi tanpa dan dengan asam sitrat, berdasarkan uji t pada Gambar 4. Menunjukkan hasil perbandingan kadar lemak yang cukup signifikan. Hal ini diduga adanya pengaruh asam sitrat terhadap kadar lemak dan dipengaruhi oleh kadar air. Menurut Winarno, 1992 dengan adanya air lemak dapat terhidrolisis menjadi gliserol dan asam lemak. Reaksi ini dapat dipercepat oleh basa, asam dan enzim [8].

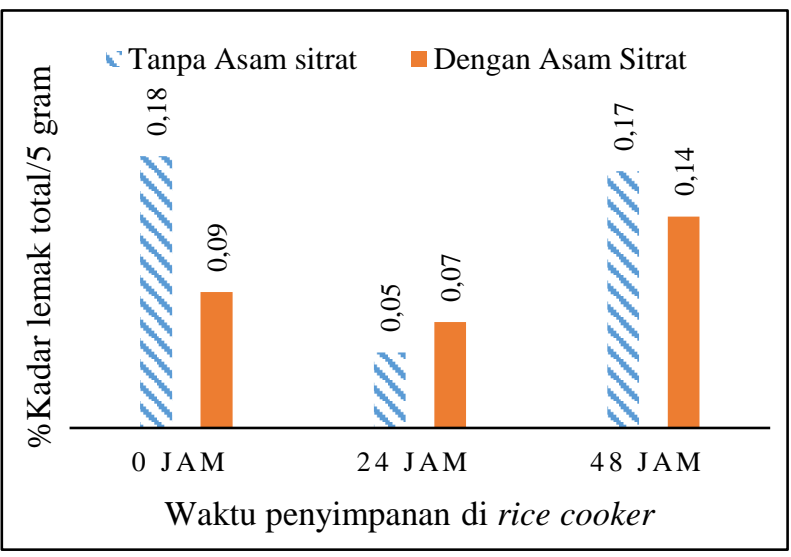

Gambar 4. Hasil analisis kadar lemak total
Pada nasi tanpa dan dengan asam sitrat dihitung persentase kenaikan dan penurunan setiap penyimpanan. Kenaikan dan penurunan kadar lemak terjadi diduga adanya faktor kadar air dan pemanasan yang terus menerus. Tabel $\mathbf{1 2}$. menunjukkan perbandingan nasi tanpa dan dengan asam sitrat pada berbagai penyimpanan.

Tabel 12. Persentase penurunan atau kenaikan kadar lemak total setiap penyimpanan pada nasi tanpa dan dengan asam sitrat

\begin{tabular}{cccc}
$\begin{array}{c}\text { Waktu } \\
\begin{array}{c}\text { Penyimp } \\
\text { anan } \\
\text { (jam) }\end{array}\end{array}$ & $\begin{array}{c}\text { \% kadar } \\
\text { lemak total } \\
\text { tanpa asam } \\
\text { sitrat }\end{array}$ & $\begin{array}{c}\text { \% kadar } \\
\text { lemak total } \\
(+) \text { asam } \\
\text { sitrat }\end{array}$ & $\begin{array}{c}\text { \%kenaikan } \\
\text { atau } \\
\text { penurunan }\end{array}$ \\
\hline 0 & 0,18 & 0,09 & 50,00 (turun) \\
24 & 0,05 & 0,07 & 28,57 (naik) \\
48 & 0,17 & 0,14 & 17,65 (turun) \\
\hline
\end{tabular}

\section{Karbohidrat Total}

Karbohidrat total pada nasi di rice cooker dengan asam sitrat pada penyimpanan 0,24 dan 48 jam mengalami penurunan dan kenaikan. Hal-hal yang mempengaruhinya antara lain kadar air, kadar nitrogen total dan kadar lemak total. Tabel 13. menunjukkan persentase kenaikan dan penurunakan kadar karbohidrat total setiap penyimpanan.

Tabel 13. Karbohidrat total dan persentase penurunan atau kenaikan setiap penyimpanan

\begin{tabular}{ccc}
\hline $\begin{array}{c}\text { Waktu } \\
\begin{array}{c}\text { Penyimpanan } \\
\text { (jam) }\end{array}\end{array}$ & $\begin{array}{c}\text { \% kadar } \\
\text { karbohidrat } \\
\text { total }\end{array}$ & \% kenaikan/penurunan \\
\hline 0 & 53,52 & $(0 \rightarrow 24) 1,38 \%$ (turun) \\
24 & 52,78 & $(24 \rightarrow 48) 2,42 \%$ (naik) \\
48 & 54.06 & \\
\hline
\end{tabular}

Pada nasi tanpa dan dengan asam sitrat, berdasarkan uji t pada Gambar 5.

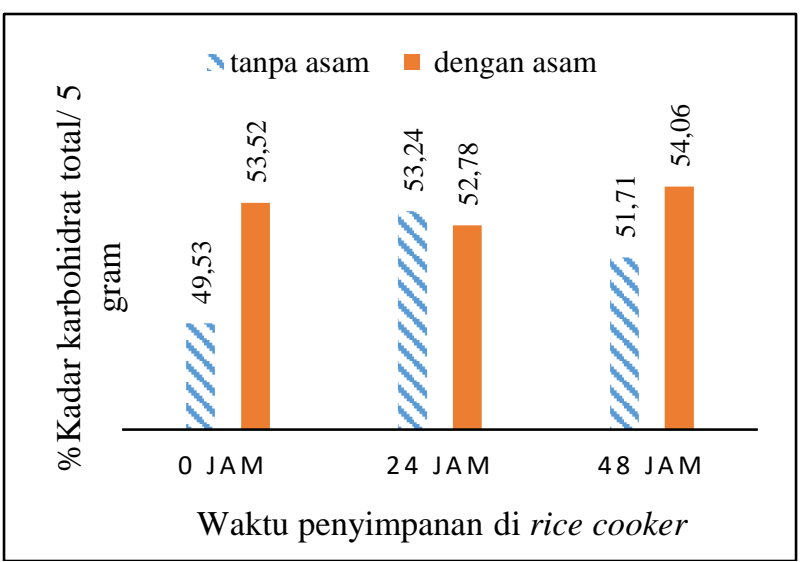

Gambar 5. Hasil analisis karbohidrat total 
Gambar tersebut memberikan pengaruh yang tidak cukup signifikan antara keduanya, sehingga dapat disimpulkan penambahan asam sitrat tidak memberikan pengaruh terhadap kandungan karbohidrat yang terkandung dalam nasi di rice cooker pada berbagai penyimpanan.

Perbandingan pesentase kenaikan dan penurunan ini disajikan untuk melihat perbandingan antara keduanya pada berbagai penyimpanan dalam Tabel 14. Perbandingan kadar karbohidrat total nasi tanpa dan dengan asam sitrat dipengaruhi oleh persentase kadar air, mineral, lemak dan protein. Kemungkinan karbohidrat total juga dipengaruhi adanya aktifitas mikroorganisme.

Tabel 14. Persentase penurunan atau kenaikan kadar karbohidrat total setiap penyimpanan pada nasi tanpa dan dengan asam sitrat

\begin{tabular}{cccc}
\hline $\begin{array}{c}\text { Waktu } \\
\text { Penyi } \\
\text { mpana } \\
\mathrm{n} \text { (jam) }\end{array}$ & $\begin{array}{c}\text { \% kadar } \\
\text { karbohidrat } \\
\text { total tanpa } \\
\text { asam sitrat }\end{array}$ & $\begin{array}{c}\text { \% kadar } \\
\text { karbohidra } \\
\text { t total }(+) \\
\text { as. Sitrat }\end{array}$ & $\begin{array}{c}\text { \%kenaikan } \\
\text { atau } \\
\text { penurunan }\end{array}$ \\
\hline 0 & 49,53 & 53,52 & 8,06 (naik) \\
24 & 53,24 & 52,78 & 0,86 (turun) \\
48 & 51,71 & 54,06 & 4,54 (naik) \\
\hline
\end{tabular}

\section{Kadar Serat Kasar}

Pada nasi dengan asam sitrat terjadi penurunan pada setiap lama waktu penyimpanan diduga karena terjadinya pengurangan serat kasar oleh aktifitas mikroorganisme pada nasi. Aktifitas mikroorganisme terjadi akibat adanya peningkatan kadar air. Kelembaban di sekitar ruang dari rice cooker diduga mempengaruhi kadar serat kasar. Tabel 15. menunjukkan persentase penurunan kadar serat kasat nasi dengan asam sitrat setiap penyimpanan.

Tabel 15. Kadar serat kasar dan persentase penurunan atau kenaikan setiap penyimpanan

\begin{tabular}{ccc}
\hline $\begin{array}{c}\text { Waktu } \\
\begin{array}{c}\text { Penyimpanan } \\
\text { (jam) }\end{array}\end{array}$ & $\begin{array}{c}\text { \% kadar } \\
\text { serat } \\
\text { kasar }\end{array}$ & \% kenaikan/penurunan \\
\hline 0 & 14,73 & $(0 \rightarrow 24) 19,69 \%$ (turun) \\
24 & 11,83 & $(24 \rightarrow 48) 26,96 \%$ (turun) \\
48 & 8,64 & \\
\hline
\end{tabular}

Perbandingan nasi tanpa dan dengan asam sitrat, berdasarkan uji t menunjukkan secara ratarata masih berada dalam keberterimaan, sehingga perbandingannya tidak cukup signifikan. Hasil ini menunjukkan penambahan asam sitrat pada nasi di rice cooker tidak mempengaruhi kadar serat kasar. Berikut Gambar 6. persentase perbandingan nasi tanpa dan dengan asam sitrat pada setiap penyimpanan.

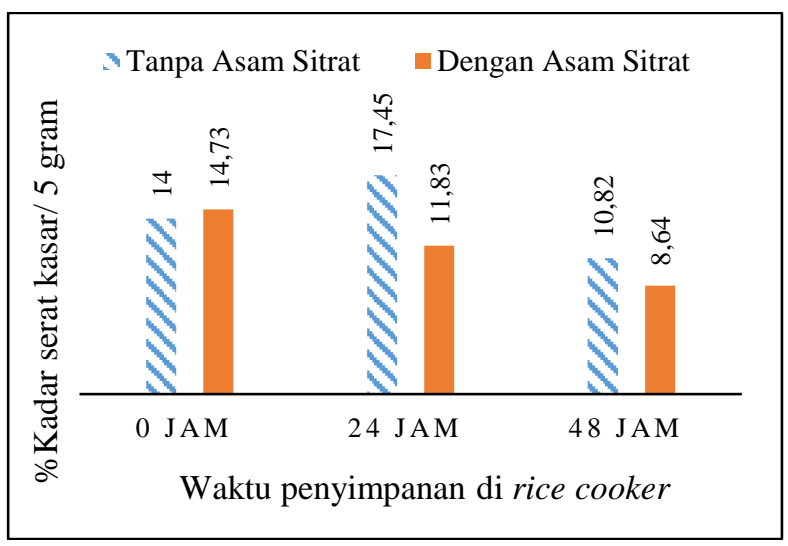

Gambar 6. Hasil analisis serat kasar

Perbandingan persentase nasi tanpa dan dengan asam sitrat mengalami kenaikan dan penurunan. Hasil persentase ini dihitung pada setiap lama penyimpanan. Tabel 16. menunjukkan persentase kenaikan atau penurunan serat kasar setiap penyimpanan pada nasi tanpa dan dengan asam sitrat.

Tabel 16. Persentase penurunan atau kenaikan kadar serat kasar setiap penyimpanan pada nasi tanpa dan dengan asam sitrat

\begin{tabular}{cccc}
\hline $\begin{array}{c}\text { Waktu } \\
\text { Penyimpa } \\
\text { nan (jam) }\end{array}$ & $\begin{array}{c}\text { \% kadar } \\
\text { serat kasar } \\
\text { tanpa asam } \\
\text { sitrat }\end{array}$ & $\begin{array}{c}\text { \% kadar } \\
\text { serat } \\
\text { kasar }(+) \\
\text { as. sitrat }\end{array}$ & $\begin{array}{c}\text { \%kenaikan } \\
\text { atau } \\
\text { penurunan }\end{array}$ \\
\hline 0 & 14,00 & 14,73 & 5,21 (naik) \\
24 & 17,45 & 11,83 & 32,21 (turun) \\
48 & 10,82 & 8,64 & 20,24 (turun) \\
\hline
\end{tabular}

\section{Bahan Ekstrak Tanpa Nitrogen (BETN)}

Pada BETN nasi dengan asam sitrat pada setiap penyimpanan mengalami kenaikan. Hal ini membuktikan bahwa penambahan asam sitrat ini tidak mempengaruhi hasil BETN karena untuk penggunaan asam sitrat pada penelitian ini masih memenuhi ambang batas menurut BPOM RI nomor 36 Tahun 2013 tentang bahan tambahan pangan. Dibuktikan dengan hasil antara nasi tanpa dan dengan asam sitrat keduanya mengalami kecenderungan yang sama, sehingga BETN yang terkandung di dalam nasi tanpa dan dengan asam sitrat perbandingannya tidak terlalu jauh. Adapun faktor-faktor yang mempengaruhi kenaikan BETN antara lain kadar air, kadar abu, kadar nitrogen total, kadar lemak total dan kadar serat kasar. Faktor lain yang mempengaruhi antara lain, adanya pemanasan yang terus menerus pada suhu konstan. Persentase kenaikan pada nasi dengan asam sitrat disajikan dalam Tabel 17. 
Tabel 17. Kadar BETN dan persentase penurunan atau kenaikan setiap penyimpanan

\begin{tabular}{ccc}
\hline $\begin{array}{c}\text { Waktu } \\
\begin{array}{c}\text { Penyimpanan } \\
\text { (jam) }\end{array}\end{array}$ & $\%$ BETN & $\begin{array}{c}\% \\
\text { kenaikan/penurunan }\end{array}$ \\
\hline 0 & 38,77 & $(0 \rightarrow 24) 5,62 \%$ \\
24 & 40,95 & (naik) \\
48 & 45,42 & $\left(24 \rightarrow \begin{array}{c}48) 10,92 \% \\
\text { (naik) }\end{array}\right.$ \\
\hline
\end{tabular}

Hasil perbandingan antara nasi tanpa dan dengan asam sitrat berdasarkan uji menunjukkan nilai $\mathrm{t}$ masih dalam wilayah kritis, artinya secara rata-rata masih menunjukkan hasil yang sama, sehingga antara nasi tanpa dan dengan asam sitrat tidak memiliki perbandingan yang cukup signifikan, serta penambahan asam sitrat pada nasi di rice cooker tidak cukup berpengaruh terhadap kadar BETN. Berikut Gambar 7. menunjukkan persentase BETN nasi tanpa dan dengan asam sitrat pada berbagai penyimpanan.

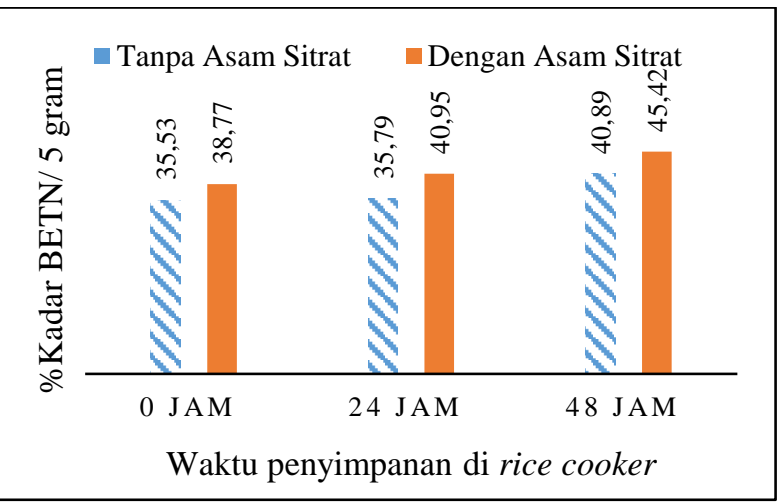

Gambar 7. Hasil BETN (bahan ekstrak tanpa nitrogen)

Persentase antara nasi tanpa dan dengan asam sitrat keduanya mengalami kenaikan pada setiap waktu penyimpanan di rice cooker. naik turunya hasil BETN dipengaruhi oleh persentase kadar air, mineral, protein, lemak dan serat kasar. Berikut Tabel 18. menunjukkan perbandingan persentase BETN antara nasi tanpa dan dengan asam sitrat.

Tabel 18. Persentase penurunan atau kenaikan BETN setiap penyimpanan pada nasi tanpa dan dengan asam sitrat

\begin{tabular}{cccc}
\hline $\begin{array}{c}\text { Waktu } \\
\text { Penyimpa } \\
\text { nan (jam) }\end{array}$ & $\begin{array}{c}\text { \% kadar } \\
\text { BETN } \\
\text { tanpa asam } \\
\text { sitrat }\end{array}$ & $\begin{array}{c}\text { \% kadar } \\
\text { BETN } \\
(+) \text { as. } \\
\text { sitrat }\end{array}$ & $\begin{array}{c}\text { \%kenaikan } \\
\text { atau } \\
\text { penurunan }\end{array}$ \\
\hline 0 & 35,53 & 38,77 & 9,12 (naik) \\
24 & 35,79 & 40,95 & 14,42 (naik) \\
48 & 40,89 & 45,42 & 11,08 (naik) \\
\hline
\end{tabular}

\section{SIMPULAN}

Dari hasil penelitian dan pembahasan pada penelitian ini maka dapat disimpulkan sebagai berikut : lama penyimpanan nasi $(0,24$ dan 48 jam) di rice cooker mempengaruhi kadar air, kadar nitrogen total, kadar lemak total, karbohidrat total, serat kasar dan kadar BETN tetapi tidak mempengaruhi kadar abu ; penambahan asam sitrat pada nasi di rice cooker dengan penyimpanan ke- 0,24 dan 48 jam mempengaruhi kadar lemak total.

\section{UCAPAN TERIMA KASIH}

Penulis mengucapkan terima kasih kepada Laboratorium Kimia UIN SGD Bandung atas penyediaan alat dan bahan serta diskusi penelitian ini.

\section{REFERENSI}

[1] Muli Novianti, Vanny M A Tiwow, and Kasmudin Mustapa, "Analisis Kadar Glukosa pada Nasi putih dan Nasi Jagung dengan Menggunakan Metode Spektronik 20," Jurnal Akademika Kimia, vol. 6, no. 2, pp. 107-112, May 2017.

[2] Luh Made Widhyasari, Ni Luh Nova Dilisca Dwi Putri, and Putu Ayu Parwati, "Penentuan Kadar Karbohidrat pada Nasi Putih dalam Proses Pemanasan Rice cooker dengan Variasi Waktu," Program Studi Analis Kesehatan STIKes Wira Medika, Bali, 2017.

[3] Yessi Hermawati, Ainur Rofieq, and Poncojari Wahyono, "Pengaruh Konsentrasi Asam Sitrat terhadap Karakteristik Ekstrak Antosianin Daun Jati serta Uji Stabilitasnya dalam Es Krim," in Prosiding Seminar Nasional Pendidikan Biologi, tema "Peran Biologi dan Pendidikan Biologi dalam Menyiapkan Generasi Unggul dan Berdaya Saing Global", Malang, 2015, pp. 301-308.

[4] Andy Agus Priyanto, Jayus , and Niken Widya Palupi, "Evaluasi Mutu Nasi Hasil Pemasakan Beras Varietas Ciherang dan IR-66 dengan Rasio Beras dan Air yang Berbeda," Berkala Ilmiah Pertanian, vol. 1, no. 1, 2015.

[5] Radella Hervidea, Zulkifli , and Lulus Lande, "Pengaruh Asam Sitrat, Aluminium dan Interaksinya terhadap Pertumbuhan Kecambah Kedelai (Glycine $\max$ L.) Varietas Anjasmoro," Jurnal Penelitian Pertanian 
Terapan, vol. 16, no. 3, pp. 132-138, September 2016.

[6] Aninda Ayu Arizka and Joko Daryatmo, "Perubahan Kelembaban dan Kadar Air Teh Selama Penyimpanan pada Suhu dan Kemasan yang Berbeda," Jurnal Aplikasi Teknologi Pangan, vol. 4, no. 4, pp. 124-129, 2015.
[7] Yesshinta Risnawanti, "Komposisi Proksimat Tempe yang Dibuat dari Kedelai Lokal dan Kedelai Impor," Universitas Muhammadiyah Surakarta, Surakarta, Artikel Publikasi Ilmiah 2015.

[8] F G Winarno, Kimia Pangan dan Gizi. Jakarta, Indonesia: PT. Gramedia Pustaka Utama, 1992. 